\title{
Two cases with lichen planus pigmentosus inversus accompanying ankylosing spondylitis and diabetes mellitus
} Liken planus pigmentozusa eșlik eden ankilozan spondilit ve diabetes mellitusu
olan iki hasta

(1) Yeșim Akpınar Kara

Yüksek Ihtisas University Faculty of Medicine Koru Hospital, Clinic of Dermatology, Ankara, Turkey

\begin{abstract}
Lichen planus pigmentosus (LPP) is an inflammatory dermatosis with an unknown etiology characterized by dark brown-black macules, papules and patches. LPP is considered as a rare variant of lichen planus (LP), but it differs from the LP by the absence of nail and oral area involvement and pruritus. LPP is most common on sun-exposed areas and less frequently seen in the axilla, inguinal or submammary regions. In the literature, very few cases have been reported to be associated with LPP. Herein, we reported two cases with LPP accompanied by ankylosing spondylitis and high levels of adrenocorticotropic hormone along with diabetes mellitus.
\end{abstract}

Keywords: Lichen planus pigmentosus inversus, anklosing spondylitis, diabetes mellitus, autoimmune diseases

Öz

Lichen planus pigmentozus (LPP) etiyolojisi bilinmeyen, koyu kahverengi-siyah makül, papül ve plaklarla karakterize enflamatuvar dermatozlardandır. LPP lichen planus'un (LP) nadir görülen bir varyantı olarak düşünülmekle birlikte tırnak ve oral bölge tutulumu görülmemesi ve kaşıntı olmaması ile LP'den ayrılır. LPP genellikle güneş maruziyeti olan bölgelerde ve daha az sıklıkla da aksilla, inguinal bölge ya da submammarian bölgede görülür. Literatürde LPP'ye eşlik eden hastalıkla birlikte sunulan çok az sayıda olgu bildirilmiştir. Biz burada, ankilozan spondilitin ve serum adrenokortikotropik hormon yüksekliği ile birlikte diabetes mellitusun eşlik ettiği LPP'li iki olguyu bildirdik.

Anahtar Kelimeler: Liken planus pigmentozus inversus, ankilozan spondilit, diabetes mellitus, otoimmün hastalık

\section{Introduction}

Lichen planus pigmentosus (LPP) is a chronic pigmentary disorder that shows diffuse or reticulated hyperpigmented macules ${ }^{1}$. LPP is categorized into many variants according to its location, distribution and morphology ${ }^{2}$. Sub-types such as actinic, linear, zosteriform and inversus have been defined so $\operatorname{far}^{3,4}$. The patches are usually symmetrical in distribution but may be found in a segmental, zosteriform, or blaschkoid pattern. The exact etiology is unknown. An autoimmune attack is generally accepted, as demonstrated by the inflammatory infiltrate of T-lymphocytes with varying populations of CD4+ and CD8+ cells, and the autoreactive cytotoxic T-lymphocytes are implicated as the effector cells, which cause degeneration and destruction of keratinocytes ${ }^{5,6}$. Herein we report two cases of LPP in association with autoimmune disease such as ankylosing spondylitis and other disease such as diabetes mellitus.

\section{Case Report}

Patient 1: A 32-year-old male patient with Fitzpatrick skin type 5, two-year pruritic papules on his right arm with a brownishbrown macules developed within 1 year on the face. He said that the lesions on the arm were treated when he applied a cortisone cream but then they recurred. There was no history

Address for Correspondence/Yazışma Adresi: Yeşim Akpınar Kara MD, Yüksek intisas University Faculty of Medicine Koru Hospital, Clinic of Dermatology

Ankara, Turkey Phone: +90 5323969352 E-mail: yesim_akpinar@yahoo.com Received/Geliş Tarihi: 15.04.2019 Accepted/Kabul Tarihi: 30.09.2019 ORCID: orcid.org/0000-0003-3834-1858

CCopyright 2020 by Turkish Society of Dermatology and Venereology

Turkderm - Turkish Archives of Dermatology and Venereology published by Galenos Yayınevi. 
of prolonged exposure on the lesion site. Medical history included the use diclofenac sodium tablets in ankylosing spondylitis for 8 years only in the presence of back pain. The examination revealed dark brownblack macules in the right/left malar region and the right axilla and, erythematous red-brown papules in the right forearm medial region. (Figure 1) There was no oral or nail involvement. The routine laboratory data were within normal limits.

Patient 2: A 55-year-old female patient with Fitzpatrick skin type 3 has developed brown reticular hyperpigmented macules around her breast
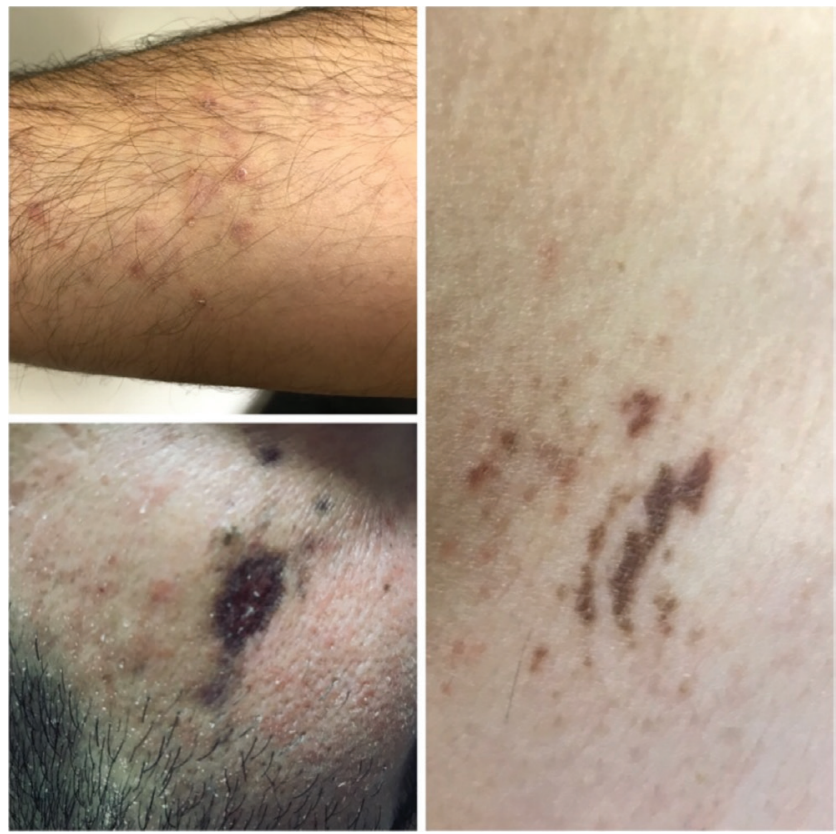

Figure 1. Brown-black macules in the malar region and the axilla, erythematous red-brown papules in the forearm
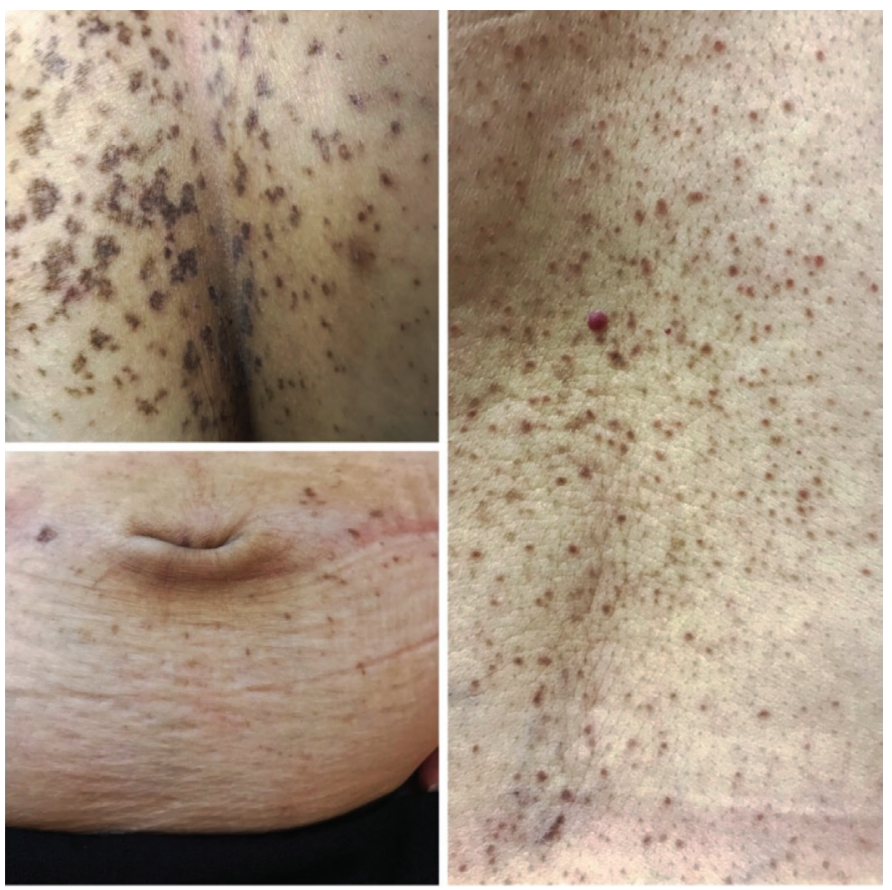

Figure 2. Brown papules were in the lumbar region and around the umblicus with reticulated brown macules in both submamarian regions and navel and, red-brown papular lesions in the lumbar region in the last 6 months. No medication was used for treatment. No chronic disease was included in the medical history. During the examination, brown papules were seen in the lumbar region and around the umblicus along with reticulated dark brown macules in both submammary regions. (Figure 2) The routine laboratory data of fasting glucose level was $283 \mathrm{mg} / \mathrm{dL}$ ( $\mathrm{n}=70-99 \mathrm{mg} / \mathrm{dL})$, adrenocorticotropic hormone (ACTH) $(72.77 \mathrm{pq} / \mathrm{mL})(\mathrm{n}=7.2-63.3 \mathrm{pq} / \mathrm{mL})$ and protein $(++)$ and glucose $(++)$ were tested positive in urine analysis. The patient was diagnosed with diabetes mellitus and was started antidiabetic therapy.

In all these cases, skin biopsies showed some examples of hyperkeratinized stratified squamous epithelium, irregular acanthosis and hypertrophy in the epithelial layer, hydropic degeneration in basal lamina, papillary edema, perivascular inflammatory infiltration and pigmentary incontinence with melanophages (Figure 3).

Mometasone furoate $0.1 \%$ cream ( 2 times/day) treatment was used for both of the two patients and then they were monitored.

\section{Discussion}

LPP is most commonly seen in the upper extremities and the trunk such as the face and neck, and rarely in the lower extremities and the flexural areas. In 2001, Pock et al. ${ }^{4}$ found that in a case of 7 patients, $90 \%$ of the patients developed lesions on intertriginous areas, which was defined as LPP-inversus. Variants of LP can be present in patients with LPP, such as the common papular type or rare types like bullous or actinic LP. Usually, there is no pruritus, and involvement of oral mucosa is rare as in $\mathrm{LP}^{1}$. In two of our patients, typical LP papules were associated with the disease and there was no pruritus. No mucosal or oral involvement was found in both patients.

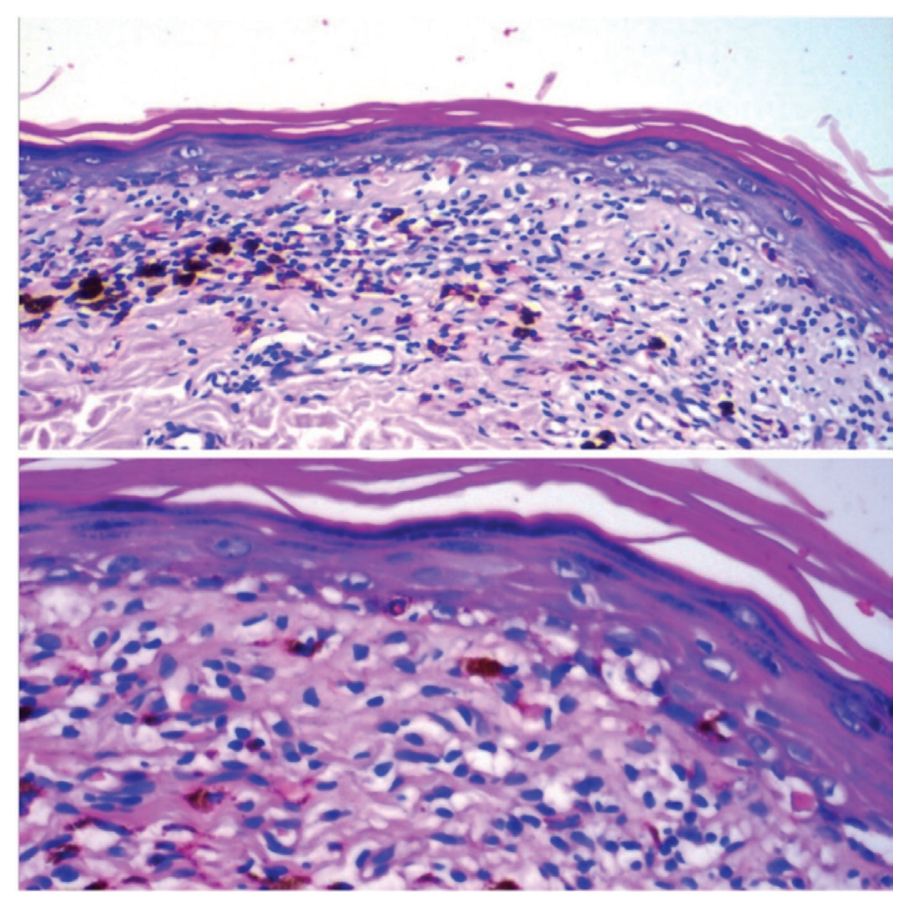

Figure 3. Hyper-keratinized squamous epithelium, hydropic degeneration in basal lamina and perivascular inflammatory infiltration and pigmentary incontinence with melanophages (hematoxylin and eosin, $x 400$ ) 
Although the etiology of LPP is unknown; drugs, sun exposure, internal malignancy, liver diseases, impaired carbohydrate metabolism have been proposed as pathogenic factors ${ }^{7}$. Some researches proposed that LPP was a Koebner phenomenon, which develops as a result of wearing tight clothing ${ }^{8}$. Some researchers reported that cytotoxic activity induced by CD8 T lymphocytes against basal keratinocytes played a role in the etiology ${ }^{9}$.

LPP is considered to be among dermatoses that cause acquired hyperpigmentation. The differential diagnosis should include erythema discronicum perstans, actinic lichen planus, Riehl melanosis and fixed drug eruption. In our first patient, hyperpigmented macules in sunexposed areas were considered to be differential diagnosis. However, the lesions in the axillary area proved otherwise. The patient was asked about the cutaneous drug reaction due to the history of diclofenac sodium in ankylosing spondylitis, but since these lesions developed in the no medication period and pigment incontinence was prominent in the histopathological findings and consistent with LPP, the medical history was not considered as the etiology of the disease. Recent studies have shown that LPP inversus also plays a role in T lymphocyteinduced cytotoxic activity against basal keratinocytes as in classical LP7. Kashima et al. ${ }^{10}$ reported that the immunohistochemical studies of two Japanese patients with LPP-inversus revealed CD8 (+) T-cell infiltration with keratinocyte damage in the epidermis and upper dermis, and a high content of CD1a (+) cells in the epidermis, focal expressions of human leukocyte antigen (HLA)-DR on keratinocytes. Kanwar et al. ${ }^{1}$ reported a linear deposition of immunoglobulin $\mathrm{M}$ or C3 in the basal membrane in the direct immunofluorescence study. It is known that the same autoimmune mechanism where cytotoxic T-cell response is generated and genetic predisposition and autoimmunity of ankylosing spondylitis and LPP are also responsible for the etiopathogenesis in ankylosing spondylitis, which is one of the sero-negative spondyloarthropathies, genetically associated with HLA-B2711.

Bhat et al. ${ }^{12}$ found that $26 \%$ of 30 clinically diagnosed LPP patients reported associations such as hypertension, diabetes mellitus, hypothyroidism and epilepsy. Karn et al. ${ }^{13}$ found that thyroid peroxidase autoantibodies were significantly higher in 54 patients with LPP compared to the control group. In the second patient we reported, diabetes mellitus was associated with LPP with elevated levels of serum ACTH. LPP has been associated with endocrinopathies in a study from Mexico, including type two diabetes in $38 \%$. These associations may be due to the chronic inflammatory state in patients with LPP, which may produce insulin resistance $\mathrm{e}^{14,15}$.

Although the lesions are generally resistant to treatment in LPP, oral steroids, topical corticosteroid and tacrolimus are used ${ }^{16}$. Spontaneous remission may occur in some cases or the disease may persist for many years despite treatment.

In the literature, there are previous reports of some diseases accompanying LPP such as antinuclear antibodies, frontal fibrosing alopecia, acrokeratosis of Bazex, head and neck carcinomas, hepatitis $C$ infection and Nephrotic syndrome ${ }^{17-20}$. We have reported these cases in order to draw attention to fact LPP is not only caused by immune dysregulation but also associated with autoimmune diseases such as ankylosing spondylitis and carbonhydrate metabolism disorders such as diabetes mellitus in the etiology.

Acknowledgment: I would like to thank Hasan Basri Sener who supported to histopathological image and helped me get results of better quality.

\section{Ethics}

Informed Consent: Informed consent was obtained from our patient. Peer-review: Externally peer-reviewed.

Financial Disclosure: The authors declared that this study received no financial support.

\section{References}

1. Kanwar AJ, Dogra S, Handa S, Parsad D, Radotra BD: A study of 124 Indian patients with lichen planus pigmentosus. Clin Exp Dermatol 2003;28:481-5.

2. Bhutani LK, Bedi TR, Pandhi RK, Nayak NC: Lichen planus pigmentosus Dermatologica 1974;149:43-50.

3. Cho S, Whang KK: Lichen planus pigmentosus presenting in zosteriform pattern. Dermatol 1997;24:193-7.

4. Pock L, Jelínková L, Drlík L: Lichen planus pigmentosus-inversus. J Eur Acad Dermatol Venereol 2001;15:452-4.

5. Patel $A B$, Kubba $R$, Kubba $A$ : Clinicopathological correlation of acquired hyperpigmentary disorders. Indian J Dermatol Venereol Leprol 2013;79:36775

6. Lage D, Juliano PB, Metze K, de Souza EM, Cintra ML: Lichen planus and lichenoid drug-induced eruption: A histological and immunohistochemical study. Int J Dermatol 2012;51:1199-205

7. Shai A, Halevy S: Lichen planus and lichen planus-like eruptions: Pathogenesis and associated disease. Int J Dermatol 1992;31:379-84.

8. Majima $Y$, Yagi $H$, Ikeda $Y$, Ito $T$, Tokura $Y$ : Two cases of lichen planus pigmentosus inversus: Possible causative role of tightly fitting underclothes. Eur J Dermatol 2013:23:904-5.

9. Dizen Namdar N, Kural E, Pulat O, Metineren MH, Sarici G: Lichen planus pigmentosus-inversus: 5 Turkish cases. J Eur Acad Dermatol Venereol 2016;30:450-2.

10. Kashima A, Tajiri A, Yamashita A, Asada Y, Setoyama M: Two Japanese cases of lichen planus pigmentosus-inversus. Int I Dermatol 2007;46:740-2.

11. Koehler L, Kuipers JG, Zeidler H: Managing seronegative spondyloarthritis. Rheumatology 2000;39:360-8.

12. Bhat RM, Mathanda TR, Jayaprakash CS, Dandakeri S: Clinical, histopathological characteristics and immunohistochemical findings in lichen planus pigmentosus. Indian J Dermatol 2017;62:612-7.

13. Karn D, Kc S, Timalsina M: Lichen planus pigmentosus. A study for association of Thyroid Dysfunction. Kathmandu Univ Med J (KUMJ) 2016;14:36-40.

14. Torres J, Pena Romero AG, Reyes E: Lichen planus pigmentosus in patients with endocrinopathies and hepatitis C. J Am Acad Dermatol 2013;68:139.

15. Robles-Mendes JC, Rizo-Frias P, Herz-Ruelas ME, Pandya AG, Ocampo Candiani J: Lichen planus pigmentosus and its variants: Review and update. Int J Dermatol 2018;57:505-14.

16. Kim BS, Aum JA, Kim HS, et al: Coexistence of classic lichen planus and lichen planus pigmentosus-inversus: resistant to both tacrolimus and clobetasol propionate ointments. J Eur Acad Dermatol Venereol 2008;22:106-7.

17. Parodi G, Parodi A, Guarrera M, Cannata G, Piccardo G: Lichen pigmentosus with scarring alopecia and circulating antinuclear antibodies. Int J Dermatol 1990;29:227-8.

18. Sassolas B, Zagnoli A, Leroy JP, Guillet G: Lichen planus pigmentosus associated with acrokeratosis of Bazex. Clin Exp Dermatol 1994;19:70-3.

19. Vachiramon $V$, Suchonwanit $P$, Thadanipon $K$. Bilateral linear lichen planus pigmentosus associated with hepatitis $\mathrm{C}$ virus infection. Case Rep Dermatol 2010;2:169-72.

20. Mancuso G, Berdondini RM: Coexistence of lichen planus pigmentosus and minimal change nephrotic syndrome. Eur J Dermatol 2009;19:389-90 